\title{
Survival, Dispersal, and Potential Soil-Mediated Suppression of Phytophthora ramorum in a California Redwood-Tanoak Forest
}

\author{
E. J. Fichtner, S. C. Lynch, and D. M. Rizzo
}

Department of Plant Pathology, University of California-Davis, Davis 95616.

Accepted for publication 27 January 2009.

\begin{abstract}
Fichtner, E .J., Lynch, S. C., and Rizzo, D. M. 2009. Survival, dispersal, and soil-mediated suppression of Phytophthora ramorum in a California redwood-tanoak forest. Phytopathology 99:608-619.

Because the role of soil inoculum of Phytophthora ramorum in the sudden oak death disease cycle is not well understood, this work addresses survival, chlamydospore production, pathogen suppression, and splash dispersal of the pathogen in infested forest soils. Colonized rhododendron and bay laurel leaf disks were placed in mesh sachets before transfer to the field in January 2005 and 2006. Sachets were placed under tanoak, bay laurel, and redwood at three vertical locations: leaf litter surface, litter-soil interface, and below the soil surface. Sachets

were retrieved after 4, 8, 20, and 49 weeks. Pathogen survival was higher in rhododendron leaf tissue than in bay tissue, with $>80 \%$ survival observed in rhododendron tissue after 49 weeks in the field. Chlamydospore production was determined by clearing infected tissue in $\mathrm{KOH}$. Moist redwood-associated soils suppressed chlamydospore production. Rain events splashed inoculum as high as $30 \mathrm{~cm}$ from the soil surface, inciting aerial infection of bay laurel and tanoak. Leaf litter may provide an incomplete barrier to splash dispersal. This 2-year study illustrates annual $P$. ramorum survival in soil and the suppressive nature of redwood-associated soils to chlamydospore production. Infested soil may serve as primary inoculum for foliar infections by splash dispersal during rain events.
\end{abstract}

Phytophthora ramorum, the cause of sudden oak death (SOD) is an exotic plant pathogen that has caused extensive mortality in coastal forests in California since the mid-1990s, inciting a fatal canker disease of susceptible oak (Quercus spp.) and tanoak (Lithocarpus densiflorus) $(37,38)$. The pathogen has additionally invaded a small area in southwestern Oregon, causing tanoak mortality as well as infections on native Rhododendron spp. and other understory hosts (38). P. ramorum has an extensive and expanding host range of over 40 plant genera, and nearly all of California's dominant tree species in mixed-evergreen and redwood-tanoak forests are potential hosts $(16,38)$. The pathogen also causes nonlethal infections on numerous hardwood and coniferous forest tree species, understory shrubs, and herbaceous plants $(11,16)$. Current disease management strategies focus on preventing the spread of the pathogen from infested to uninfested areas (38) and imposing quarantines on nursery plants and plant products (1). Nevertheless, the pathogen continues to be detected in nursery stock $(3,20,36,46,47)$ and the risk of movement of infected ornamental plants poses a continued threat to the health and sustainability of forests.

The epidemiology of $P$. ramorum in California is influenced by the region's Mediterranean climate, with the onset of the annual disease cycle corresponding to the fall rainy season and the survival phase corresponding to the hot, dry summer months $(12,38)$. The seasonal sporulation of $P$. ramorum in California is correlated to rain events and warm temperatures, with nonlethal foliar lesions on bay laurel (Umbellularia californica) supporting prolific multicyclic sporangia production $(12,38)$. Foliage and small twigs of tanoak also support sporulation (9) but sporangia are not produced on oak cankers and cankers on the main stem of tanoak (12). Chlamydospore production has been observed on

Corresponding author: E. J. Fichtner; E-mail address: ejfichtner@ucdavis.edu

doi:10.1094/PHYTO-99-5-0608

(c) 2009 The American Phytopathological Society symptomatic bay leaves (E. J. Fichtner, unpublished data) but the role of chlamydospores in pathogen survival is unknown. $P$. ramorum survives the hot, dry summer in a portion of symptomatic bay leaves, and may generally be isolated into culture by sampling the margin of foliar lesions (8). Infected bay leaves are more likely to abscise, fostering an inoculum reservoir at the forest floor. Soil inoculum levels are greater under bay laurel than either redwood (Sequoia sempervirens) or tanoak, and are also greater in soil than in leaf litter, suggesting that rapid transfer of inoculum from the litter layer to the soil enhances survival potential (15).

Summer survival of $P$. ramorum in forest soils potentially serves as an inoculum reservoir at the onset of the fall rainy season (15). Soil drying is a limiting factor for $P$. ramorum survival (15) but the survival potential of the pathogen under annual alternating soil wetting and drying conditions is unknown. Furthermore, pathogen survival potential in infected bay laurel leaves in litter and soil is unknown. Although symptoms of $P$. ramorum have only been observed in aboveground plant parts (16), soil inoculum may play an important role in SOD epidemiology. Asymptomatic root infections of $P$. ramorum have been documented in rhododendron and viburnum $(3,5,6,35,40)$ and in tanoak roots excavated from forest soils (34). The observed dieback of tanoak sprouts following the clear-cut and burn treatments in the Oregon eradication zone (17) may be related to persistence of inoculum in infested soil. The pathogen has been shown also to infect the roots of weeds found in ornamental container culture (41).

P. ramorum produces abundant chlamydospores in vitro $(37,47)$ and in buried, infected rhododendron leaves (15). Preliminary studies suggest that chlamydospores of $P$. ramorum lose viability by drying at $30 \%$ relative humidity at room temperature for 30 min (10). Chlamydospores of $P$. cinnamomi may persist in moist soil for years $(23,48)$. Only low soil levels of $P$. cinnamomi are needed to initiate disease, and chlamydospore populations of $P$. cinnamomi in soil are quantifiable (39). Similarly, low levels of chlamydospores of $P$. ramorum are required to initiate root infec- 
tions on rhododendron and viburnum $(5,6,40)$. However, soil baiting is ineffective for detection of chlamydospores in the $P$. ramorum system (15), presumably due to variable, slow, and infrequent chlamydospore germination $(15,43)$. In laboratory studies, redwood-associated soils inhibited chlamydospore production, suggesting a potential suppressive nature of redwood soils (15)

Though $P$. ramorum has been demonstrated to survive in soil (15) and infect roots $(3,5,6,34,35,40,41)$, the potential for splash dispersal from soil to aboveground plant parts has not been determined. Splash dispersal has been observed for other Phytophthora spp. $(25,27)$, with propagules traveling up to $60 \mathrm{~cm}$ above infested surfaces (27). The litter layer may enhance splash dispersal from infested soil (12) or provide a physical barrier to dispersal (25). The role of the litter layer in mediating splash dispersal of $P$. ramorum in infested forests is unknown.

This work investigates the role of forest soil in the SOD disease cycle, with specific objectives pertaining to four themes: distribution, survival, pathogen-suppressive soil, and splash dispersal. Specific objectives include (i) a continued investigation of seasonal distribution of $P$. ramorum in soil and leaf litter under host tree species, (ii) assessment of year-long survival potential of $P$. ramorum in infected rhododendron and bay laurel leaf tissue at the forest floor, (iii) investigation of influence of soil type on chlamydospore production, (iv) identification of the role of soil moisture in mediating chlamydospore production, and (v) determination of the potential for splash-dispersed soil inoculum to incite aboveground infections in infested forests.

\section{MATERIALS AND METHODS}

Study site. Field-based studies were conducted in a redwoodtanoak forest at Jack London State Park (JLSP) in Sonoma County, CA $\left(122^{\circ} \mathrm{W}, 38^{\circ} \mathrm{N}\right)$. Fifteen trees each of bay laurel, tanoak, and redwood were tagged for repeated sampling over time to gather a continuous multiyear data set on pathogen distribution in underlying soils and characterize the magnitude of yearly epidemics (15). Individual trees were selected to maximize distance from dissimilar overstory species (15), and tagged trees were selected within heavily infested areas previously characterized (28). The total disease incidence within bay laurel, tanoak, and redwood was $\approx 90,55$, and $10 \%$, respectively at JLSP in 2004 and 2005 (R. Cobb and S. C. Lynch, unpublished data). The parent material of the soils is residuum weathered from metavolcanics and the dominant series are Spreckles and Goulding (4). Soil characteristics varied in association with different tree species. Redwood-associated soils had higher organic matter content $(>20 \%)$ than those associated with either bay laurel or tanoak (15). Soil $\mathrm{pH}$ was 5.5 to 6.1 , with tanoak-associated soils having a lower $\mathrm{pH}$ than redwood- and bay laurel-associated soils (15). Minimum and maximum daily air temperature were recorded with a Campbell HMP45C-L10 temperature and relative humidity probe (Campbell Scientific Inc., Logan, UT) and precipitation was measured with a Texas Electronics 8-in. rain gauge (Texas Electronics Inc., Dallas).

Seasonal pathogen distribution. A prior study was conducted to assess the distribution of inoculum under the 15 tagged bay laurel, tanoak, and redwood trees from December 2003 through October 2005 (15). In the current study, pathogen distribution is presented monthly from January 2005 through December 2006, spanning the two calendar years associated with the currently presented field studies. Within $1.5 \mathrm{~m}$ of tagged trees, three soil and three leaf litter samples were collected and bulked, resulting in $\approx 0.5$-liter samples of litter and soil from each tree. Samples were returned to the lab for determination of soil moisture content and presence of $P$. ramorum by baiting. The techniques employed for pathogen baiting and determination of soil moisture were established by Fichtner et. al. (15) and are used throughout this paper.
Rhododendron cv. Colonel Coen was the only cultivar used as bait material for detection of $P$. ramorum in soil and litter throughout this study.

Pathogen survival. Ten tagged trees each of bay laurel, tanoak, and redwood were selected for assessment of year-long survival in associated soils over the calendar years of 2005 and 2006. To minimize potential for introduction of new pathogen genotypes to a natural system, an isolate of $P$. ramorum was baited from soil at JLSP for use in all studies requiring placement of inoculated plant material in the forest. Each year, $\approx 4,000$ Rhododendron cv. Colonel Coen and bay laurel leaf disks (nursery grown from a California seed source) were cut with a 1-cm-diameter cork borer, puncture wounded with a sterile pin, and placed in a single layer, abaxial side up, on moist paper towels within a closed moist chamber. Colonies of $P$. ramorum were grown for 7 days at room temperature on V8 agar, then excised from plates, chopped into $4-\mathrm{cm}^{2}$ pieces, and placed in a Waring blender with an equal volume of water. The colony suspension was blended for $30 \mathrm{~s}$ and then the resulting slurry was pipetted over the wounded leaf disks. Leaf disks were incubated on moist paper towels within an enclosed chamber for 10 days. Inoculated leaf disks were misted daily with deionized water. Ten days after inoculation, the agar was rinsed off the leaf disks. Using forceps, symptomatic leaf disks were placed in each of 720 mesh sachets. Sachets were stored in moist chambers until placement in the field the following day. To assess initial pathogen recovery, 100 inoculated leaf disks were submerged in a selective medium amended with hymexazol (PARPH) at $0.05 \mathrm{~g} /$ liter $(13,31)$.

Mesh sachets were deployed to the field during a cold, winter rainstorm on 7 January 2005, and on a mild, sunny day on 6 January 2006 . Four points were randomly selected at $1.5-\mathrm{m}$ radii from each tree to allow for destructive sampling over time. At each of the four points, two plastic cylindrical barriers were submerged to a depth of 6 to $7 \mathrm{~cm}$ in soil for paired, yet separate, incubation of infected rhododendron and bay laurel leaf disks. Cylindrical barriers were prepared by excising the base of $17-\mathrm{cm}-$ diameter horticultural plant pots. All plastic barriers were cleaned and surface sterilized prior to placement in the forest. Sachets were arranged vertically within the cylindrical barriers, with one sachet paced at each of three depths: $6 \mathrm{~cm}$ below the soil surface, the leaf litter-soil interface, and the leaf litter surface. To determine pathogen survival over annual fluctuation of soil temperature and moisture conditions, one set of vertical sachets of bay and rhododendron leaf disks were retrieved at each of four time points: 4, 8, 20, and 49 weeks after deployment.

At each of the four time points, sachets were destructively sampled and leaf disks were then submerged in PARPH for 2 weeks before determination of pathogen recovery. P. ramorum was easily identified on PARPH plates due to the distinct morphology of chlamydospores in culture. Pathogen identification on PARPH was confirmed at each collection time by transferring $\approx 10$ isolates to V8 agar for examination of morphology in pure culture. Because enhanced recovery of Phytophthora spp. has been observed after tissue hydration $(15,24)$, leaf disks designated as ' $P$. ramorum-negative' based on absence of growth on PARPH were then removed from the selective medium and incubated for 3 weeks in deionized water before being returned to PARPH for subsequent reassessment of recovery. Leaf disks retrieved after 20 and 49 weeks lacked the structural integrity necessary for completion of the hydration process; consequently, post-hydration data were gathered only for leaf disks retrieved after 4 and 8 weeks. The influence of host tree association and of vertical location on pathogen recovery over time were assessed using repeated measures analysis of variance (ANOVA) with between-subjects factors and within-subject interactions determined using a Wilks' Lambda test. All statistical analyses were conducted using SAS (SAS Institute, Cary, NC). Pathogen recovery data for leaf disks of bay laurel and rhododendron were analyzed separately. 
Soil samples $(\approx 0.5$ liter) were taken from each tree upon the introduction of inoculum to the field and at each sampling time. Soil samples were collected from the top $7 \mathrm{~cm}$ of the soil, excluding the leaf litter layer. Samples were taken both inside and directly outside the cylindrical barrier in an effort to compare the level of inoculum between artificially infested soil (inside) and soil with natural inoculum loads (outside). Using previously described techniques (15), soil samples were baited for P. ramorum and gravimetric soil moisture content was determined. Soil-moisture content associated with tree species over time was assessed with repeated measures ANOVA.

Chlamydospore production. After recovery of $P$. ramorum from leaf disks was determined on PARPH, all leaf disks $(n=900$ bay laurel, $n=900$ rhododendron) from the 4-week sample time were incubated in $1 \mathrm{M} \mathrm{KOH}$ for 3 weeks to render tissue translucent or clear enough to visualize chlamydospores under the light microscope (14). Five chlamydospore counts were taken under the $\times 10$ field of view, an area of $3.8 \mathrm{~mm}^{2}$, and the average number of chlamydospores per field of view was recorded. For both the infected bay laurel and rhododendron leaf disks, chlamydospore counts were analyzed separately with a GLM procedure and Waller-Duncan K-ratio test $(K=100)$ to determine the influence of host soil association (bay laurel, tanoak, and redwood) and vertical location (buried, litter-soil interface, and litter surface) on chlamydospore production.

Role of soil moisture in chlamydospore production. Because chlamydospore production was assessed in leaf disks buried in soils associated with 10 trees each of bay laurel, redwood, and tanoak, soils could be ranked based on their relative inhibition or promotion of chlamydospore production. The three soils associated with the highest and lowest average chlamydospore production were identified from the leaf disks retrieved in January 2005. The three soils limiting chlamydospore production were associated with redwood trees, whereas soils promoting chlamydospore production were associated with two bay laurels and one tanoak. Because these soils were potentially suppressive or conducive to $P$. ramorum, soils were collected from the field and returned to the laboratory to qualify and quantify the effect of these soils on chlamydospore production. Using surface-disinfested trowels, $\approx 1.3$ liters of soil were collected under each tree from the top $7 \mathrm{~cm}$ below the litter layer. Conducive and suppressive soils were bulked separately and allowed to dry for 10 days at room temperature. Soils were placed in 40 pots $(10$ by $10 \mathrm{~cm}$ ) and half the pots were saturated and drained to container capacity, thus establishing a complete factorial treatment design with two soil types and two moisture regimes. Rhododendron leaf disks were inoculated with the same $P$. ramorum isolate and using the same procedure employed in the survival study, Ten infected leaf disks were nested between layers of nylon mesh and buried $\approx 3 \mathrm{~cm}$ below the soil surface of each pot. Pots were then arranged in a randomized complete block design (RCBD), with each of four treatments represented in 10 blocks. Pots designated as a moist treatment were placed in petri dishes with $1 \mathrm{~cm}$ of water, establishing a soil matric potential of $-0.6 \mathrm{kPa}$ at the location of the inoculum. Each block of pots was maintained in a sealed container. Containers were opened weekly for aeration and to maintain the standing water level for moist pots. Pots were incubated at room temperature for 4 weeks and then leaf disks were retrieved for clearing and determination of chlamydospore populations by the aforementioned procedures. Upon leaf disk retrieval, five blocks were randomly selected for determination of soil moisture content and five subsamples were taken per pot. Soil was collected twice in January 2007 and used for two separate runs of the experiment.

Decomposition rates in soil and litter. Because chlamydospore production trends associated with soil type differed in leaf disks sampled in January 2005 and January 2006, we hypothesized that soil microbial activity, a factor closely linked to soil moisture $(7,33,42)$, may influence the suppressive nature of soils. Decomposition rates in soil and leaf litter were used as an indirect measure of soil microbial activity in the field from July 2006 through July 2007. Two partially submerged cylindrical barriers $(17 \mathrm{~cm}$ in diameter) were placed within $1.5 \mathrm{~m}$ of each of the tagged bay laurel, tanoak, and redwood trees used in the survival study, and cellulose segments were incubated in the barriers for consecutive 2-week intervals either $6 \mathrm{~cm}$ below the soil surface or at the interface of soil and leaf litter. Soil samples were collected concurrent with exchange of cellulose segments to determine soil moisture content at each collection point. Decomposition rates were averaged over samples from the two replicates at each tree. Spectra/Por molecularporous membrane tubing (VWR Scientific, Batavia, IL) was utilized as a cellulose substrate because mineral contaminants can easily be washed after removal from the field. The membrane tubing was cut into $56-\mathrm{cm}^{2}$ squares, oven dried at $60^{\circ} \mathrm{C}$, and placed in nylon mesh sachets before transfer to the field. Upon retrieval from the field, the membranes were washed thoroughly with deionized water and oven dried at $60^{\circ} \mathrm{C}$, and decomposition rates were calculated as percent mass loss over time. The influence of tree association on soil moisture content and soil and litter decomposition rates were determined using a repeated-measures ANOVA with between-subjects factors and within-subject interactions determined using a Wilks' Lambda test.

Assessment of biologically mediated suppression. The potential for microbe-mediated suppression of chlamydospore production in redwood soils was assessed by comparing chlamydospore production in steamed versus unsteamed soil. The three most suppressive soils were collected from JLSP, bulked, and thoroughly mixed. Then, half the soil was steamed $30 \mathrm{~min}$ at $99^{\circ} \mathrm{C}$ on two consecutive days. Soils were then placed into 10 replicate pots (10 by $10 \mathrm{~cm}$ ) of each treatment and filled with deionized water to container capacity. Each pot was placed in a petri dish with $1 \mathrm{~cm}$ of water, establishing a soil matric potential of $-0.6 \mathrm{kPa}$ at $3 \mathrm{~cm}$ below the soil surface, where 10 infected rhododendron leaf disks were buried. Leaf disks were inoculated with the same isolate and technique used in the aforementioned studies. Pots of each treatment were paired and maintained in 10 sealed containers, and containers were opened weekly for aeration and to maintain the standing water level for moist pots. Pots were incubated at room temperature for 3 weeks; then, leaf disks were retrieved for clearing and determination of chlamydospore populations by the aforementioned procedures. Chlamydospore counts were averaged per pot and the difference in chlamydospore production between steamed and unsteamed soil was determined using a paired $t$ test. The experiment was conducted twice.

Splash dispersal of soil inoculum. The potential for soil inoculum to infect aboveground tissues of tanoak and bay laurel was investigated at JLSP during two rain events in February 2007. Forest soil was collected under uninfected bay laurel at JLSP and placed in 64 containers $\left(700 \mathrm{~cm}^{2}\right)$ to a depth of 5 to $6 \mathrm{~cm}$. Fifty infected rhododendron leaf disks ( $1 \mathrm{~cm}$ in diameter) were placed on the soil surface of each container. Leaf disks were inoculated with the same $P$. ramorum isolate and technique as in the aforementioned studies. The leaf disk inoculum was lightly dusted with soil and half of the containers were covered with a layer of leaf litter, $\approx 3 \mathrm{~cm}$ thick. Leaf litter was collected under uninfected bay laurel trees and mixed thoroughly in a bucket before dispersing over infested soil surfaces. A complete factorial treatment design was established to observe potential splash dispersal from either bare soil or litter-covered soil. Treatments were replicated eight times, with each replicate located under a group of redwood trees. Several strategies were employed to ensure that infection of suspended plant tissues resulted from splash dispersal of introduced inoculum rather than natural forest inoculum. Both the soil and leaf litter were collected under uninfected bay laurel trees. Additionally, containers were set in groups of redwood trees, 
utilizing the dense redwood stands as a barrier to inoculum drift from infected bay laurel. Infected redwood trees support minimal sporangia production compared with bay laurel (9). Because sporangia may disperse up to $15 \mathrm{~m}$ from infected bay laurel (12), the centers of these eight groups of redwood were all at least $15 \mathrm{~m}$ from infected bay laurel, thereby minimizing potential for inoculum drift into the experimental system. Seven asymptomatic twigs, containing two leaves each of either bay laurel or tanoak, were suspended above each container at either 8 or $30 \mathrm{~cm}$ above the inoculum source. To maintain turgidity of bait materials, twigs
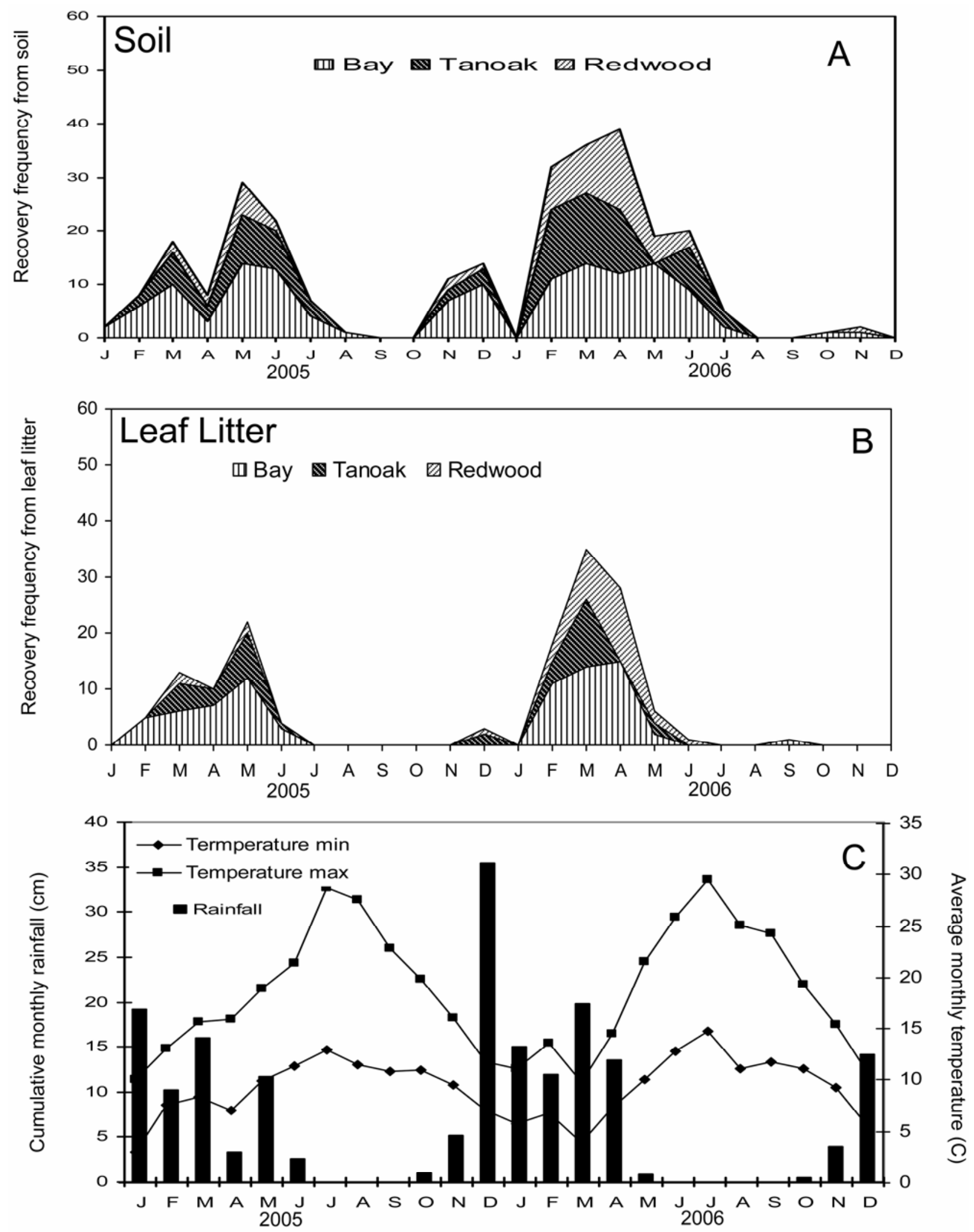

Fig. 1. Temporal distribution of Phytophthora ramorum in soil and leaf litter in association with bay laurel, tanoak, and redwood was assessed monthly. Frequency of recovery from $\mathbf{A}$, soil and $\mathbf{B}$, leaf litter, with recovery frequency associated with each species $(n=15)$ stacked for a cumulative potential frequency of 45 . $\mathbf{C}$, Cumulative monthly rainfall and minimum and maximum temperatures recorded at Jack London State Park during 2005 and 2006. 
were incubated in water-filled floral tubes elevated on thin, metal stakes. Bait materials were incubated for 1 week in the field, then returned to the laboratory and incubated in moist chambers until symptom development. Symptomatic tissues were isolated onto PARP to determine the percentage of bait tissues infected. Fresh asymptomatic bait materials were used for each of two rain events but the original leaf disk inoculum was used for both rain events. The effect of inoculum exposure and suspension height on percent infection was determined using an ANOVA and differences between treatments were assessed with a Waller-Duncan K-ratio test $(K=100)$. Percent infection of tanoak and bay laurel twigs were analyzed separately.

\section{RESULTS}

Seasonal pathogen distribution. $P$. ramorum was baited from soils and litter throughout the winter rainy seasons, with a higher recovery frequency observed in 2006 than in 2005 (Fig. 1A and B). Recovery frequency generally declined during the hot, dry summer months; P. ramorum was baited from soil through August 2005 but was undetectable in soils in August 2006 (Fig. 1A). The rainfall patterns in 2005 were atypical, in that precipitation continued into June (Fig. 1C), supporting late spring sporulation events (9). Furthermore, the summer of 2006 was characterized by exceptionally persistent hot temperatures, as evidenced by the higher minimum and maximum monthly temperatures in June and July 2006 compared with 2005 (Fig. 1C). The pathogen was baited from soils and litter associated with bay laurel, tanoak, and redwood (Fig. 1A and B). In general, at any given sampling time when $P$. ramorum was recovered from soil or litter, at least a portion of the positives were associated with bay laurel (Fig. 1A and B). The single exception was in December 2005, where the pathogen was detected in litter associated with tanoak and redwood, with no recovery observed in bay laurel-associated litter (Fig. 1B). Furthermore, P. ramorum was recovered from one bay laurel litter sample in September 2006, before the start of the fall rainy season (Fig. 1B and $\mathrm{C}$ ).

Pathogen survival. Measurements for soil moisture content were generally greater throughout the 2005 season than the 2006 season (Table 1). Upon introduction of inoculum to the field, soil moisture contents were 50 to $70 \%$ and 31 to $38 \%$ in January 2005 and 2006, respectively (Table 1). Soil moisture contents of redwood-associated soils were higher than those of bay laurel- or tanoak-associated soils at every collection time over both years (Table 1).

During the 2005 season, only vertical location of inoculum significantly affected survival of $P$. ramorum in both rhododendron (Fig. 2A) $(P \leq 0.0001)$ and bay laurel leaf disks (Fig. 2B) $(P \leq 0.0001)$. In 2005, pathogen recovery from soil-incubated leaf disks declined between January and May, then significantly increased between May and December (Fig. 2A and B), illustrating a rebound in pathogen recovery over the latter portion of the year.

In the 2006 season, the survival of $P$. ramorum in both rhododendron and bay laurel leaf disks was only affected by an

TABLE 1. Measurement of soil moisture content corresponding to leaf disk retrieval time points in the year-long survival study of Phytophthora ramorum at the forest floor

\begin{tabular}{|c|c|c|c|c|c|}
\hline \multirow[b]{2}{*}{ Year, species } & \multicolumn{5}{|c|}{ Soil moisture $(\% \pm \mathrm{SE})^{\mathrm{z}}$} \\
\hline & Initial & 4 weeks & 8 weeks & 20 weeks & 49 weeks \\
\hline \multicolumn{6}{|l|}{2005} \\
\hline Bay laurel & $49.9 \pm 3.2$ & $31.7 \pm 3.8$ & $57.1 \pm 3.6$ & $47.3 \pm 2.9$ & $42.5 \pm 2.7$ \\
\hline Redwood & $70.4 \pm 9.9$ & $34.5 \pm 5.1$ & $71.3 \pm 5.1$ & $71.6 \pm 6.4$ & $60.7 \pm 5.5$ \\
\hline \multicolumn{6}{|l|}{2006} \\
\hline Bay laurel & $34.2 \pm 1.6$ & $53.6 \pm 1.5$ & $51.6 \pm 5.1$ & $50.0 \pm 5.4$ & $56.6 \pm 2.0$ \\
\hline
\end{tabular}

${ }^{\mathrm{z}}$ Soil moisture content was determined upon initial introduction of inoculum to the field in January 2005 and 2006, then after 4, 8, 20, and 49 weeks, in conjunction with sampling for pathogen survival. Average percent gravimetric soil moisture was determined for five subsamples from each of 10 trees of bay laurel, tanoak, and redwood. Standard error (SE) values were determined for soil moisture content associated with each host-tree species at each sample time.
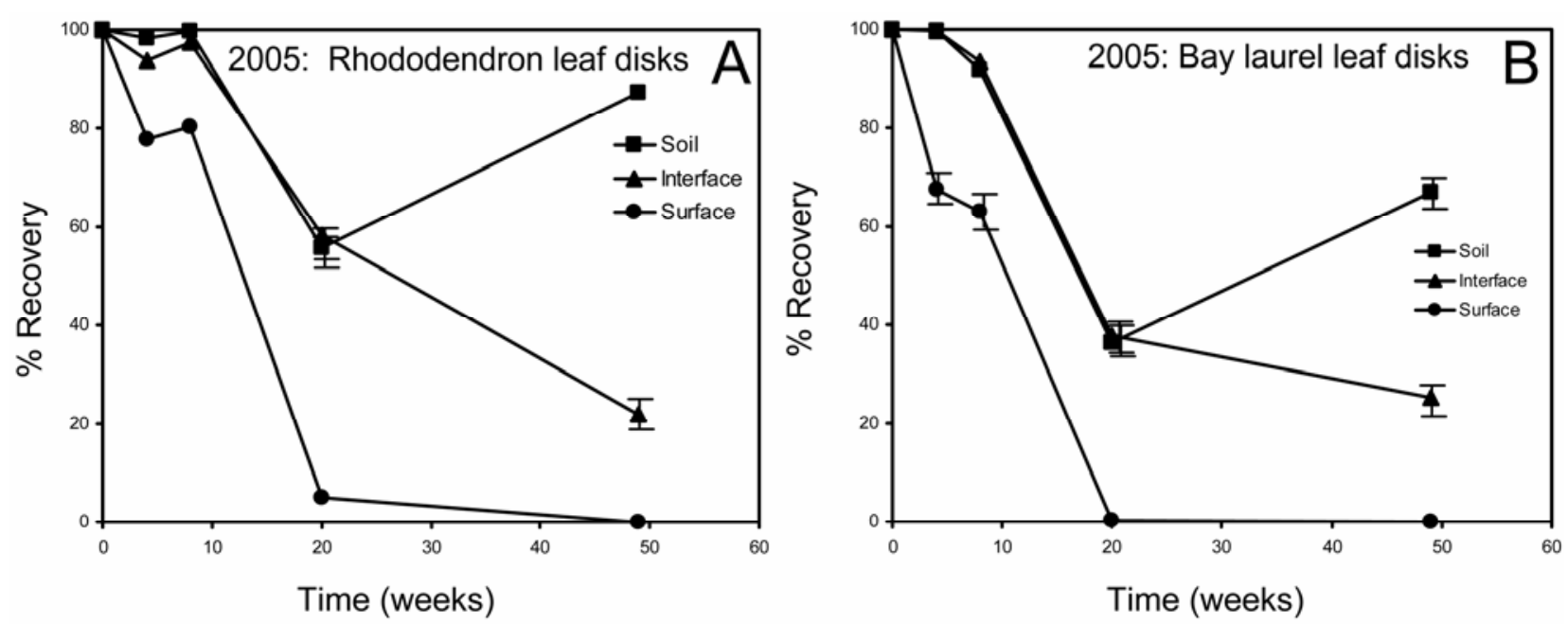

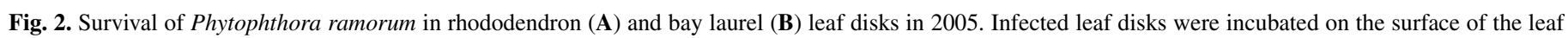

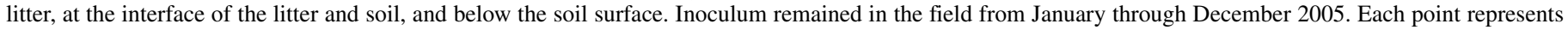

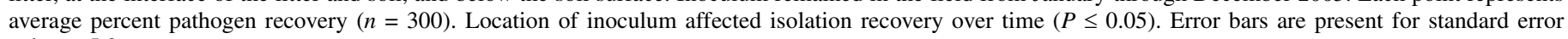
values $\geq 5.0$. 
interaction of vertical location of inoculum and host soil association $(P \leq 0.05)$ (Fig. 3). For example, after 49 weeks of incubation in the field, tanoak-, bay laurel-, and redwood-associated soils exhibited 22, 62, and $77 \%$ pathogen recovery, respectively, in infected rhododendron leaf disks (Fig. 3A). Also, until May 2006, inoculum placed under bay laurel trees supported generally higher recovery in surface-incubated leaf disks than those incubated under redwood or tanoak (Fig. 3C and F). In general, pathogen survival was higher in 2005 than in 2006, as illustrated by the higher recovery of $P$. ramorum from soil-incubated and soil-litter interface-incubated leaf disks 49 weeks after placement in the field (Figs. 2 and 3).

Soil baiting of $P$. ramorum from inside and outside the cylindrical barriers revealed a generally higher frequency of recovery inside the cylinders throughout the year (Table 2). In 2005, after 49 weeks of incubation of leaf disks in soil, the pathogen was recovered from $>75 \%$ of the cylinders, whereas recovery outside the barriers was only $37 \%$ (Table 2). In December 2006, however, $P$. ramorum was baited from soil in cylinders containing infected rhododendron leaf disks with approximately twice the
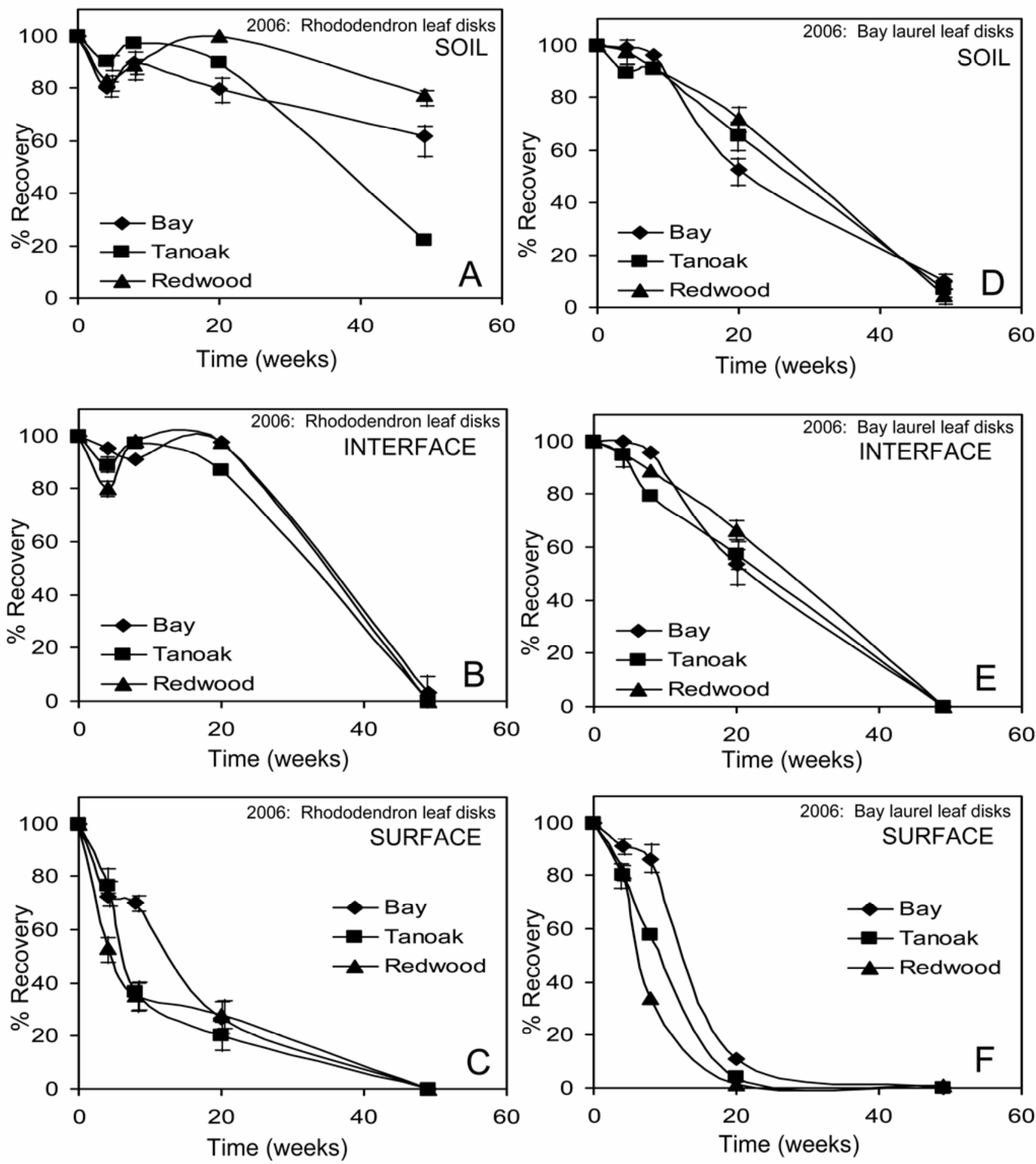

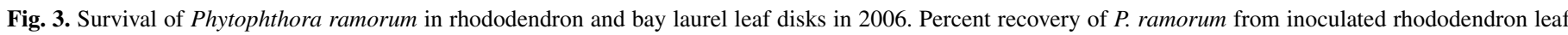

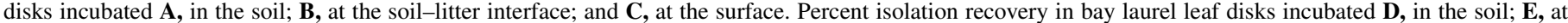

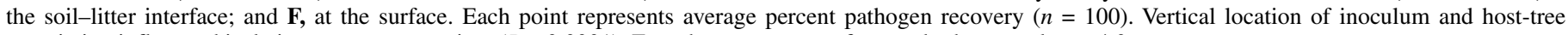
association influenced isolation recovery over time $(P \leq 0.0001)$. Error bars are present for standard error values $\geq 4$.0. 
TABLE 2. Percent recovery of Phytophthora ramorum inside and outside cylinders containing infected bay laurel and rhododendron leaf disks

\begin{tabular}{lcccc}
\hline & \multicolumn{4}{c}{ Recovery $(\%)^{\mathrm{z}}$} \\
\cline { 2 - 5 } Year, samples $^{\mathrm{y}}$ & 4 weeks & 8 weeks & 20 weeks & 49 weeks \\
\hline 2005 & 100 & 100 & 93 & 77 \\
Bay laurel disks & 93 & 90 & 97 & 90 \\
Rhododendron disks & 40 & 30 & 57 & 37 \\
Outside cylinder & & & & \\
2006 & 100 & 97 & 90 & 20 \\
Bay laurel disks & 97 & 80 & 93 & 43 \\
Rhododendron disks & 57 & 43 & 70 & 23 \\
Outside cylinder & 57
\end{tabular}

y Soil within cylinders was infested with either $P$. ramorum-infected bay laurel or rhododendron leaf disks, with 10 infected leaf disks buried $\approx 6 \mathrm{~cm}$ below the soil surface.

${ }^{\mathrm{z}}$ Soil samples were collected both inside and outside each cylinder, and then baited with rhododendron leaves for determination of presence of $P$. ramorum. Soils inside the cylinders were artificially infested with $P$. ramorum by introduction of colonized leaf tissue; soils outside the cylinders were exposed to natural inoculum in the forest. Values represent the percent of samples positive for the pathogen at each sample time $(n=30)$. Soil samples were collected concurrent with leaf disk inoculum 4, 8, 20, and 49 weeks after inoculum deployment.

TABLE 3. Percent change in Phytophthora ramorum recovery from rhododendron and bay laurel leaf disks after a 3-week incubation in deionized water in 2005

\begin{tabular}{lcc}
\hline & \multicolumn{2}{c}{ Change $(\%)^{\mathrm{z}}$} \\
\cline { 2 - 3 } Sampley & 4 weeks & 8 weeks \\
\hline Rhododendron & 3.4 & 1.7 \\
Soil & 12.0 & 2.9 \\
Interface & 21.6 & 0.9 \\
Surface & & 0.3 \\
Bay laurel & 0 & 0 \\
Soil & 0.6 & 0 \\
Interface & 2.7 & \\
Surface & & \\
\hline
\end{tabular}

y Infected rhododendron and bay laurel leaf disks were placed in mesh sachets and distributed under 10 trees each of bay laurel, tanoak, and redwood. Mesh sachets were placed at either of three vertical locations: below the soil surface, at the interface of the soil and litter, and at the litter surface. At each of four sample times, infected leaf disks $(n=300)$ were assessed from each vertical location to determine pathogen recovery. In 2005, tree species association had no statistical affect on pathogen recovery.

${ }^{\mathrm{z}}$ Post-hydration recovery data was recorded on inoculated leaf disks incubated in the field for 4 and 8 weeks. The change in pathogen recovery contributed by hydration was determined by removing $P$. ramorum-negative leaf disk tissue from PARPH, incubating the leaf disks in deionized water for 3 weeks, and then resubmerging the tissue in PARPH. frequency as soil samples collected from cylinders containing infested bay laurel leaf disks and those gathered outside the cylinders (Table 2).

Hydration of $P$. ramorum-negative leaf disks in deionized water enhanced pathogen recovery by up to $21.6 \%$ in rhododendron disks (Table 3 ) and $7.4 \%$ in bay laurel disks (Table 4). In Tables 3 and 4 , post-hydration recovery data are categorized by factors significantly affecting pathogen recovery in the survival study. For example, 2005 hydration-stimulated recovery is categorized by vertical location of inoculum, and 2006 data is categorized by both vertical location of inoculum and host association of soil. Enhanced recovery was generally higher in samples incubated for 4 weeks in the field than those incubated for 8 weeks, and rhododendron leaf disks exhibited higher hydration-stimulated recovery than bay disks (Tables 3 and 4).

Chlamydospore production. In both 2005 and 2006, chlamydospore production within infected rhododendron leaf disks was influenced by an interaction of vertical location and host tree association $(P \leq 0.05)$ (Fig. 4). In 2005, rhododendron leaf disks incubated in redwood-associated soils exhibited $\approx 60 \%$ fewer chlamydospores than disks incubated in either tanoak- or bay laurelassociated soils (Fig. 4A); this trend was not observed in 2006 (Fig. 4B). Chlamydospore populations in bay laurel leaf disks also were affected by an interaction of vertical location and host tree association in $2005(P \leq 0.05)$ (Fig. 5A) and $2006(P \leq 0.05)$ (Fig. 5B), though the trends were different than those observed with rhododendron disks. In 2005, bay laurel leaf disks incubated at the litter surface exhibited significantly fewer chlamydospores than those incubated in soil or at the interface of soil and litter (Fig. 5A). In 2006, bay laurel leaf disks incubated at the interface exhibited more chlamydospores in redwood-associated soils than in either bay laurel- or tanoak-associated soils (Fig. 5B).

Role of soil moisture in chlamydospore production. In a controlled experiment, chlamydospore production within infected rhododendron leaf disks was influenced by an interaction of soil type and soil moisture status $(P \leq 0.0001)$ (Table 5). Because treatments performed similarly over two runs of the experiment, chlamydospore production data is averaged over runs (Table 5). The bulked suppressive field soils reduced chlamydospore production compared with the bulked conducive soils (Table 5). Soil moisture content was higher in the suppressive soil than in the conducive soil for samples maintained wet and dry (Table 5). Chlamydospore production was similar in moist and dry conducive soil; however, chlamydospore production was $40 \%$ lower in moist suppressive soil than in dry suppressive soil (Table 5).

Decomposition rates in soil and litter. Gravimetric soil moisture content was consistently higher in redwood-associated soils

TABLE 4. Percent change in Phytophthora ramorum recovery from rhododendron and bay laurel leaf disks after a 3-week incubation in deionized water in 2006

\begin{tabular}{|c|c|c|c|c|c|c|}
\hline \multirow[b]{3}{*}{ Inoculum $^{\mathrm{y}}$} & \multicolumn{6}{|c|}{ Change $(\%)^{\mathrm{z}}$} \\
\hline & \multicolumn{3}{|c|}{4 weeks } & \multicolumn{3}{|c|}{8 weeks } \\
\hline & Bay & Tanoak & Redwood & Bay & Tanoak & Redwood \\
\hline Soil & 4.5 & 1.0 & 4.8 & 0 & 0 & 3.6 \\
\hline Interface & 1.0 & 1.0 & 7.0 & 0 & 0 & 0 \\
\hline Surface & 1.0 & 2.0 & 9.0 & 0 & 0 & 0 \\
\hline \multicolumn{7}{|l|}{ Bay laurel } \\
\hline Surface & 1.0 & 3.0 & 6.0 & 0 & 0 & 0 \\
\hline
\end{tabular}

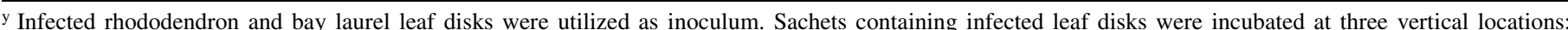
below the soil surface, at the interface of the soil and leaf litter, and at the leaf litter surface. At each of four sample times, infected leaf disks $(n=300)$ of each tissue type were assessed from each vertical location to determine pathogen recovery.

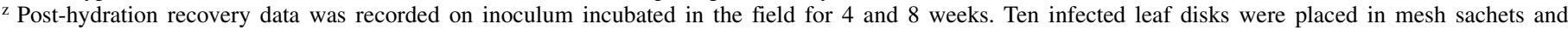
distributed under 10 trees each of bay laurel, tanoak, and redwood. In 2006, pathogen recovery was influenced by an interaction of host tree association and vertical location of leaf disks near the soil surface. The change in pathogen recovery contributed by hydration was determined by removing $P$. ramorum-negative leaf disk tissue from PARPH, incubating the leaf disks in deionized water for 3 weeks, and then resubmerging the tissue in PARPH. 
than in either bay laurel- or tanoak-associated soils (Fig. 6A). The decomposition rate of cellulose, as measured by percent mass loss, was influenced by host tree association $(P \leq 0.0001)$ (Fig. $6 \mathrm{~B})$ and by position in either soil or the litter-soil interface $(P \leq$ 0.0001 ) (Fig. 6C). Decomposition rate increased $\approx 10$-fold between August 2006 and the first rain event in October 2006 (Fig. $6 \mathrm{~B})$. After the initial rain event, soil moisture content and decomposition rate both decreased until another burst in decomposition rate was observed with subsequent rain events and soil wetting (Fig. 6.A and B). At the beginning of the fall rainy season in 2006, decomposition rates in redwood-associated soils were lower than those in either bay laurel- or tanoak-associated soils (Fig. 6B); however, decomposition rates were similar between all three host-associated soils and litter for the majority of the rainy season (Fig. 6B and C). Decomposition rates tended to be higher in the soil than at the leaf litter-soil interface during the dry summer months of 2006 and 2007 and also after the first few fall rain events in fall 2006 (Fig. 6C). During the majority of the rainy season, however, decomposition rates in soils and litter were similar among different host-tree associations (Fig. 6C).

Assessment of biologically mediated suppression. No significant difference in chlamydospore production was observed in steamed versus unsteamed soil. Average chlamydospore populations in steamed and unsteamed soil were 79 and 76 spores $/ \mathrm{mm}^{2}$, respectively, in the first run of the experiment and 19.6 and 16.1 spores $/ \mathrm{mm}^{2}$, respectively, in the second run of the experiment.

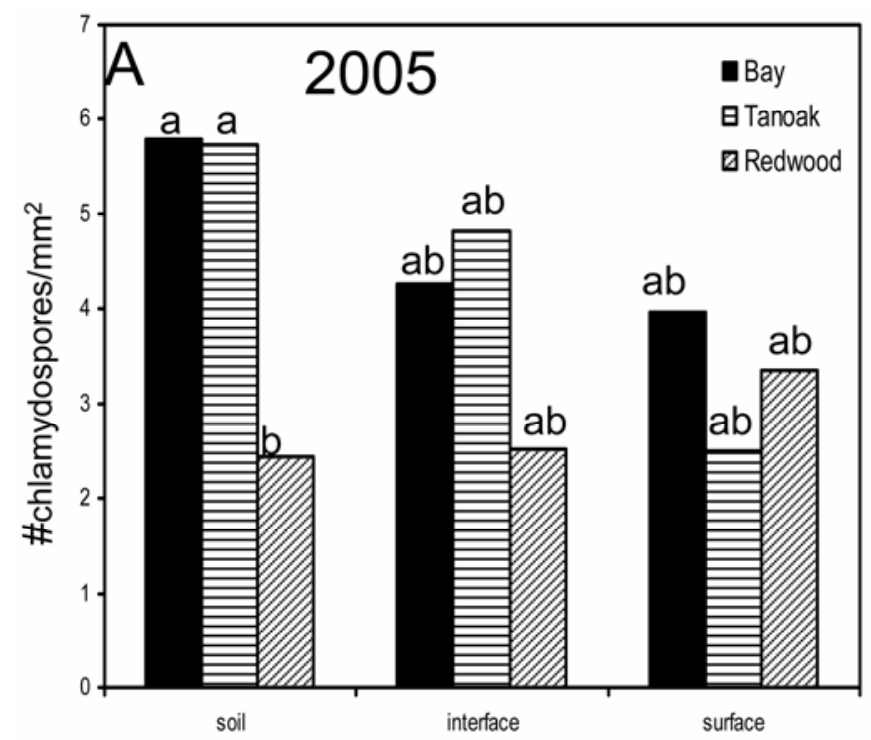

Vertical location

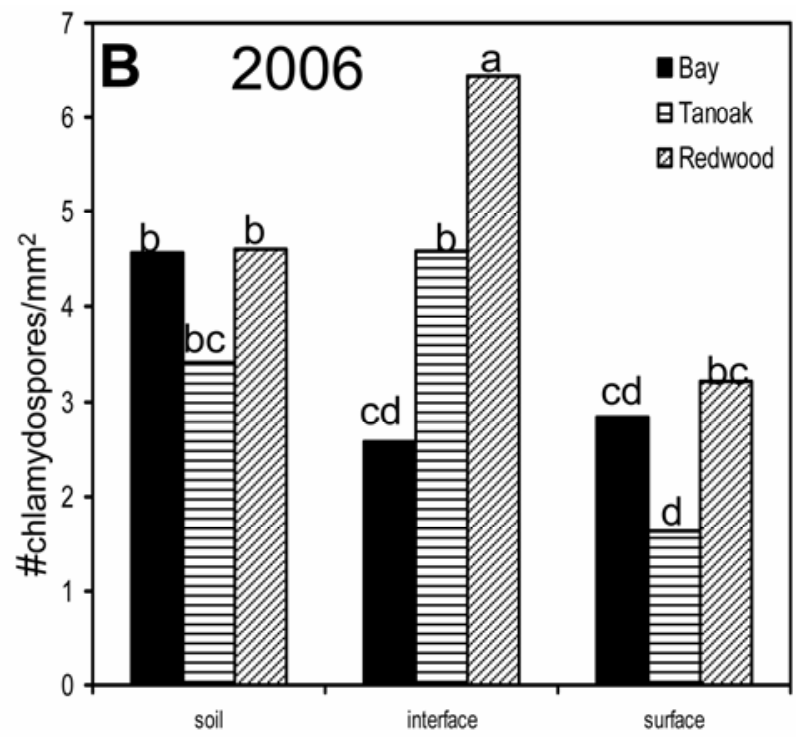

Vertical location

Fig. 4. Chlamydospore production in infected rhododendron leaf disks. All leaf disks $(n=900)$ collected after 4 weeks in the field in 2005 and 2006 were incubated in $1 \mathrm{M} \mathrm{KOH}$ until tissue was cleared of color. The average number of spores produced per square millimeter was determined for each disk by averaging five counts under the $\times 10$ field of view of the light microscope. Chlamydospore populations in A, 2005 and B, 2006. Different letters above bars designate significant differences based on the Waller-Duncan K-ratio test $(K=100)$.
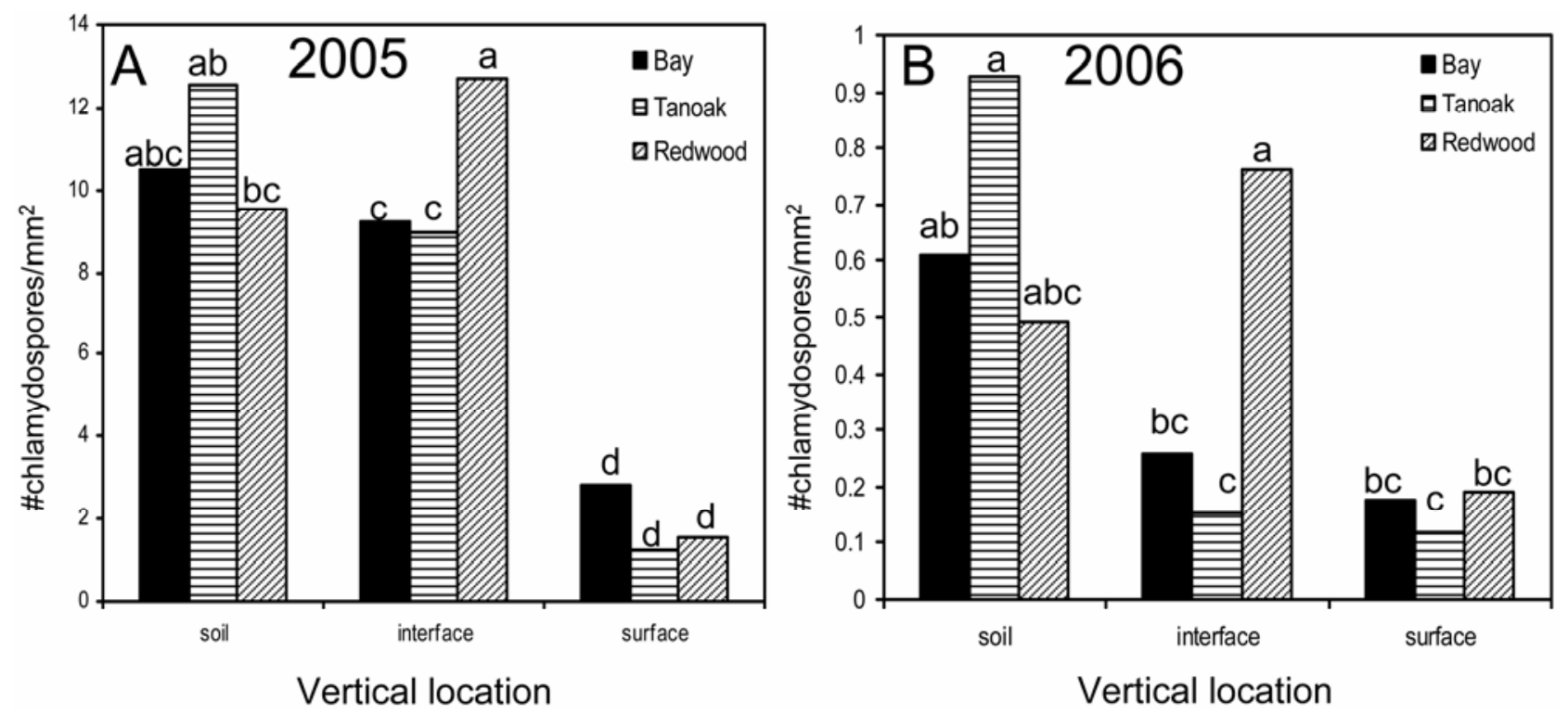

Fig. 5. Chlamydospore production in infected bay laurel leaf disks. All leaf disks $(n=900)$ collected after 4 weeks in the field in 2005 and 2006 were incubated in $1 \mathrm{M} \mathrm{KOH}$ until tissue was cleared of color. The average number of spores produced per square millimeter was determined for each disk by averaging five counts under the $\times 10$ field of view of the light microscope. Chlamydospore populations in A, 2005 and B, 2006. Different letters above bars designate significant differences based on the Waller-Duncan K-ratio test $(K=100)$. 
Splash dispersal of soil inoculum. Infection of aboveground bay laurel and tanoak twigs by splash-dispersed inoculum was influenced by an interaction of suspension height and inoculum exposure $(P \leq 0.05)$ (Table 6). Infection levels after two rain events were statistically similar for tanoak; therefore, average percent infection of tanoak was combined over two rain events (Table 6). Infection levels of bay laurel twigs differed between rain events; therefore, data from each rain event are reported separately (Table 6). In general, aboveground infections of either plant material were highest over bare soil at the $8-\mathrm{cm}$ suspension height, with infection levels reaching at least $75 \%$ in both plant materials (Table 6). Overlaying inoculum with leaf litter dramatically reduced aboveground infections of either plant material but did not eliminate infections, even at the $30-\mathrm{cm}$ suspension height (Table 6).

\section{DISCUSSION}

The persistence of $P$. ramorum in heterogeneous forest soil conditions may influence seasonal SOD epidemiology and result in long-term ecological impacts on regeneration of vegetation, forest stand dynamics, and wildlife habitat. This study demonstrates that $P$. ramorum may survive up to 49 weeks in soil, spanning the active winter disease cycle, the summer survival phase, and the successive disease cycle. Though soil may serve as a survival site by contributing an inoculum reservoir, our evidence suggests that some soils may also suppress $P$. ramorum populations by inhibiting chlamydospore production.

Environmental conditions conducive to soil drying may impede in situ survival of P. ramorum in forest soils. Phytophthora spp. tend to quickly lose viability upon soil drying (45), and laboratory experiments have corroborated that $P$. ramorum survival in soil declines with gradual drying (15). Survival of subsurface $P$. ramorum inoculum in 2006 was lower than that of 2005 , presumably due to the occurrence of multiple days with air temperatures $>40^{\circ} \mathrm{C}$. Because high temperatures cause soil drying under field conditions, it is impossible to attribute either temperature or moisture independently as limitations for $P$. ramorum survival in the 2006 season. Under laboratory conditions, temperatures $>30^{\circ} \mathrm{C}$ eliminated recovery of P. ramorum from infected rhododendron

TABLE 5. Chlamydospore production of Phytophthora ramorum in infected rhododendron leaf disks incubated in conducive and suppressive soils maintained at different moisture contents ${ }^{\mathrm{w}}$

\begin{tabular}{lcc}
\hline Soil & $\begin{array}{c}\text { No. of } \\
\text { chlamydospores } / \mathrm{mm}^{2 \mathrm{y}}\end{array}$ & $\begin{array}{c}\text { Gravimetric soil } \\
\text { moisture }(\%)^{\mathrm{z}}\end{array}$ \\
\hline Conducive dry & $6.5 \mathrm{a}$ & $19.1 \mathrm{a}$ \\
Conducive wet & $6.5 \mathrm{a}$ & $68.1 \mathrm{~b}$ \\
Suppressive dry & $4.9 \mathrm{~b}$ & $23.1 \mathrm{c}$ \\
Suppressive wet & $3.0 \mathrm{c}$ & $75.2 \mathrm{~d}$ \\
\hline
\end{tabular}

${ }^{\mathrm{w}}$ Ten Phytophthora ramorum-infected rhododendron leaf disks were placed in each of 40 mesh sachets and incubated in either conducive or suppressive soils maintained under either moist or dry conditions for 4 weeks. Different letters within columns represent significant differences based on the WallerDuncan K-ratio test $(\mathrm{K}=100)$.

${ }^{x}$ Three soils associated with the highest and lowest average chlamydospore production were identified from the leaf disks retrieved from the field survival experiment in January 2005. The three soils most conducive and suppressive to chlamydospore production were bulked separately. Infected leaf disks were incubated in soils maintained either moist or dry. Pots designated to moist treatments were placed in petri dishes with $1 \mathrm{~cm}$ of water, establishing a matric potential of $-0.6 \mathrm{kPa}$ at the location of leaf disk inoculum. y Leaf disks were incubated in $1 \mathrm{M} \mathrm{KOH}$ until tissue was cleared of color. The average number of spores $/ \mathrm{mm}^{2}$ was determined for each disk by averaging five counts from under the $\times 10$ field of view of the light microscope. The represented number of chlamydospores for each treatment is averaged over two experimental runs.

${ }^{\mathrm{z}}$ Average percent gravimetric soil content was determined upon introduction of leaf disks to pots by taking five subsamples from each pot in five randomly selected blocks. leaves and free chlamydospores buried in moist sand after 4 and 7 days, respectively (44). The results of these in vitro studies suggest that temperature may have been one limiting factor for $P$. ramorum survival at or near the soil surface in the current study.

Conditions offering protection from drying may enhance pathogen survival as evidenced by the higher recovery of $P$. ramorum from infected rhododendron than from bay laurel leaf disks incubated in redwood-associated soils throughout 2006. Soils associated with redwood trees have higher organic matter content than those associated with bay laurel or tanoak, consequently maintaining higher soil moisture content throughout the year (15). The higher soil moisture contents and more moderate summer temperatures common in coastal SOD-infested redwood-tanoak forests may promote $P$. ramorum survival compared with the JLSP site, which is $\approx 50 \mathrm{~km}$ inland and has more extreme temperature and moisture conditions than coastal forests. Additionally, the thickness of rhododendron leaves may offer resistance to drying compared with the thin bay laurel foliar tissue, thereby contributing to the higher pathogen recovery from the rhododendron leaf disks. Enhanced pathogen recovery after hydration was more prevalent in infected rhododendron leaf disks than bay laurel; however, the reason for this difference is unknown. Survival potential of other Phytophthora spp. has been shown to vary depending on type of tissue colonized (26).

Infected bay laurel and rhododendron foliage supported production of chlamydospores of $P$. ramorum both on the forest floor surface and in forest soil. These results suggest that environmental conditions may affect chlamydospore production either in soil or at the soil surface. For example, the rapid drying of infected bay laurel leaf disks at the litter surface may be responsible for the relatively low chlamydospore production in these tissues compared with those protected by a layer of litter or soil. Similarly, higher chlamydospore production was observed at the interface of litter and soil associated with redwood trees than with other host-associated soils, possibly due to the higher soil moisture content of redwood-associated soils. Though the enhanced soil moisture may promote pathogen survival between the redwood litter and soil, redwood soils were found to be suppressive to chlamydospore production in infected rhododendron leaves buried beneath the soil surface.

In order to identify potentially suppressive soils, chlamydospore production was evaluated in leaf disks that had been submerged in selective medium after incubation in the field. In laboratory studies, leaf disks were removed from soils and directly cleared for determination of chlamydospore populations, thus eliminating contact with selective medium that could affect production of chlamydospores in culture. Consequently, the information gathered on chlamydospore production in the field survival study was utilized as a precursor to studies designed to more effectively assess the suppressive nature of redwood-associated soils.

Phytophthora spp. have been shown to be suppressed by microbiostasis in soils with high microbial activities and high organic matter contents $(2,14,21,22)$. As an indirect measure of microbial activity in our study system, the decomposition rate of redwoodassociated soils was compared with that of bay laurel- and tanoak-associated soils. Assessment of decomposition rate was utilized as an alternative to measuring $\mathrm{CO}_{2}$ efflux, a direct measure of respiration, because $\mathrm{CO}_{2}$ efflux results from both root and microbial respiration. Because the decomposition rate in redwood soils was lower than that of the two mineral soils, it is unlikely that general microbiostasis results in suppressed chlamydospore production of $P$. ramorum. Additionally, chlamydospore production was similar in steamed and unsteamed redwood-associated soil, suggesting an abiotic rather than a biologically mediated mechanism of suppression. Because the redwood-associated soil was only suppressive when moist, it is possible that a soluble compound is responsible for inhibition of chlamydospore produc- 


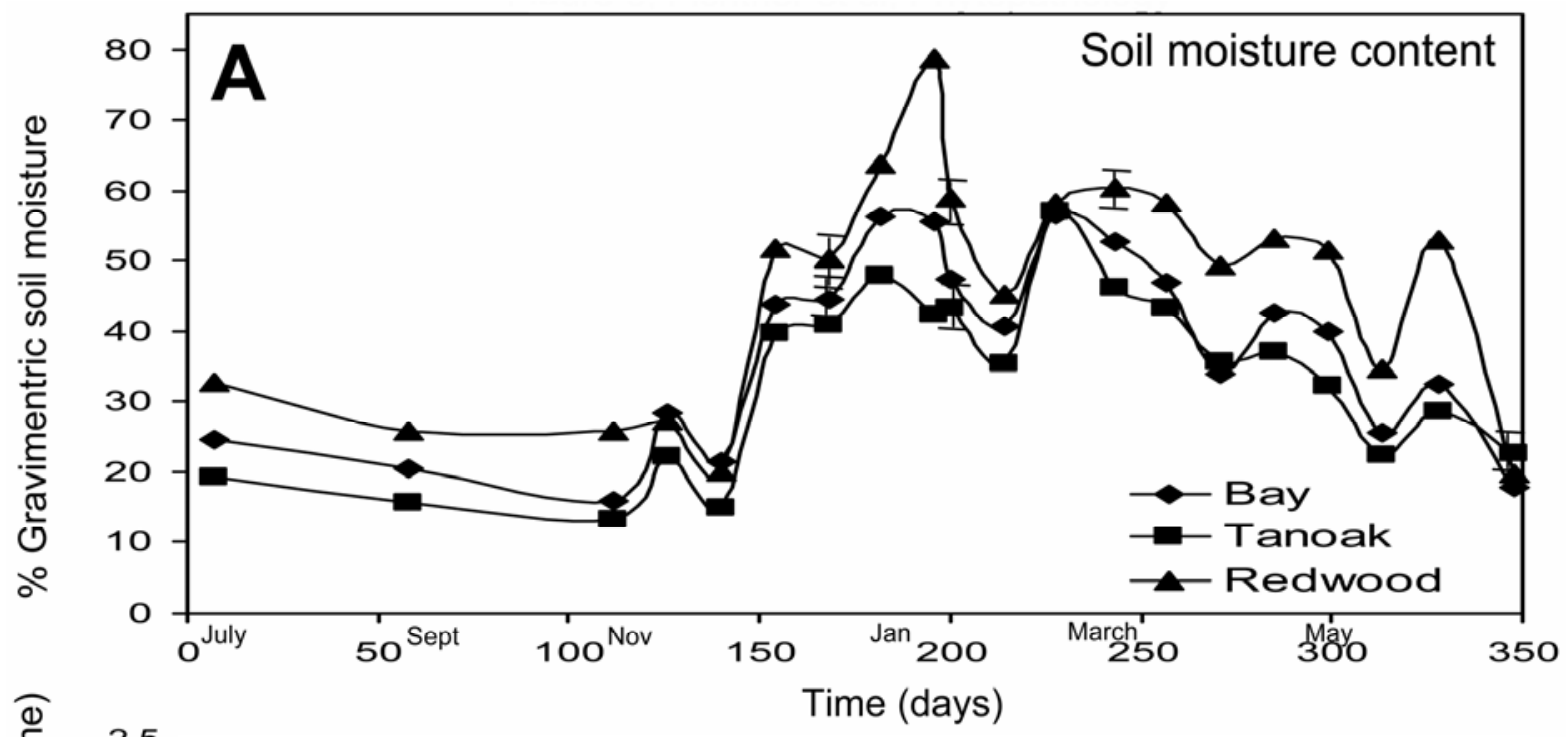

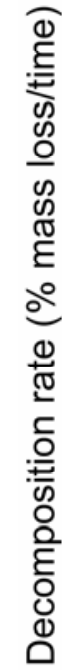
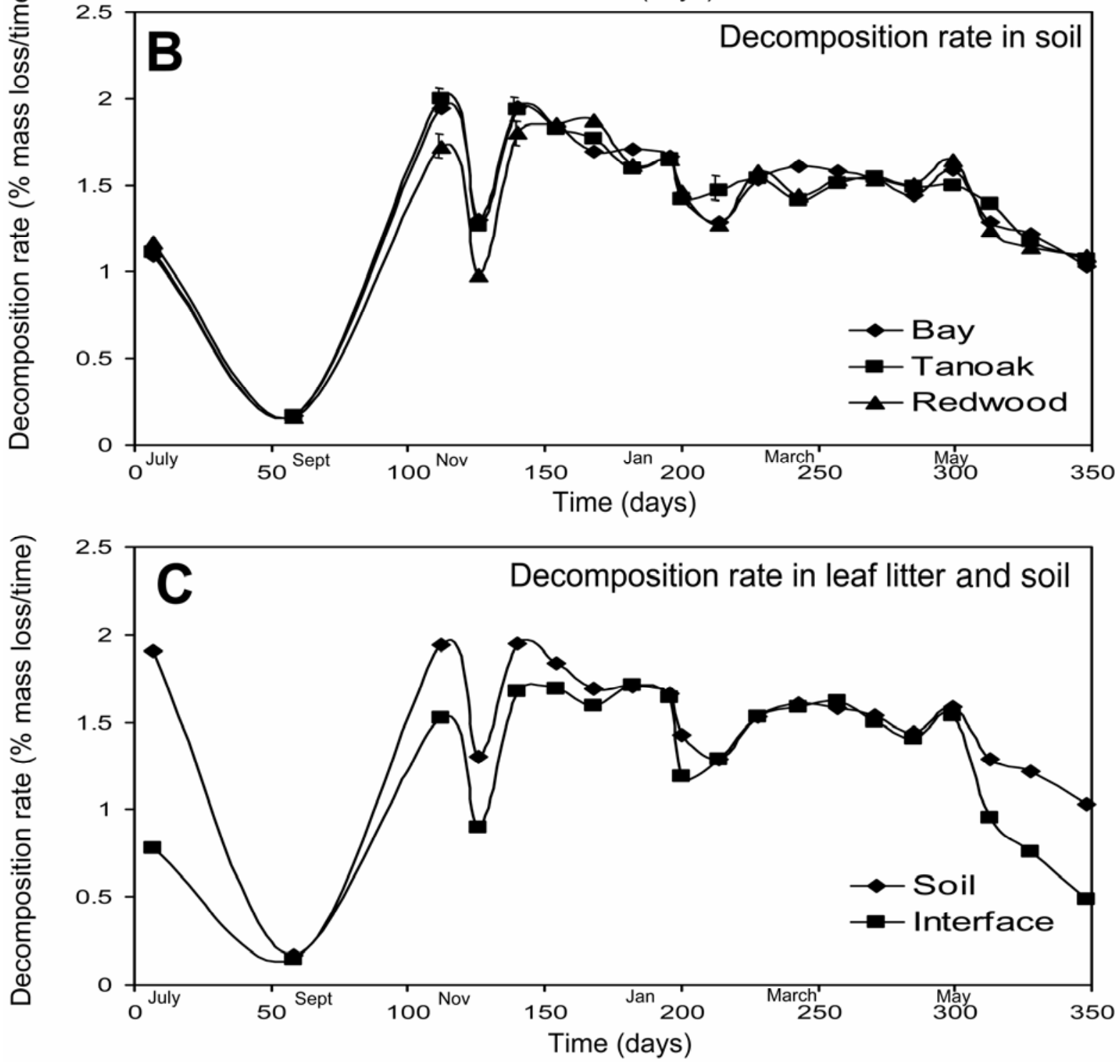

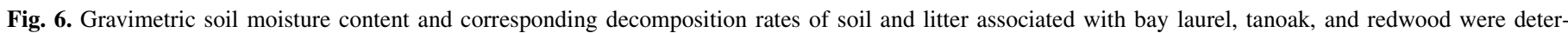
mined from July 2006 through June 2007. At $\approx 2$-week intervals, cellulose was either buried in the soil or incubated at the interface of litter and soil in association with 10 trees each of bay laurel, tanoak, and redwood. Two replicates of cellulose were placed at each location under each of 30 trees and decomposition rate was determined by assessing percent mass loss over time. A, Gravimentric soil moisture content at each collection time $(n=10)$. B, Decomposition rates of cellulose in soils associated with bay laurel, tanoak, and redwood trees $(n=40)$. C, Decomposition rates of cellulose associated with the soil and the interface of litter and soil $(n=60)$. Error bars are present for error values $>5$ in graph $\mathbf{A}$ and $>0.12$ in $\mathbf{B}$ and $\mathbf{C}$. 
tion. This hypothesis is also supported by the findings of Manter et al. $(29,30)$ that identify extractable conifer compounds with sporicidal and antimicrobial activity to $P$. ramorum.

The results of our work suggest that propagules of $P$. ramorum may be splash dispersed to at least $30 \mathrm{~cm}$ above the infested forest floor, causing infection of either tanoak or bay laurel tissues. Similar to other Phytophthora pathosystems (25), splash dispersal was limited but not eliminated by covering inoculum with a layer of leaf litter, suggesting that litter provided a physical barrier to rain splash. Because of the short duration of the splash-dispersal study, it is not likely that the litter inhibited hyphal survival of $P$. ramorum as has been observed with extended incubation of other Phytophthora spp. in leaf litter $(26,32)$.

Combining the results from the survival and splash-dispersal studies with the epidemiological work of Davidson et al. $(9,12)$ suggests that rain and wind splash result in movement of inoculum over relatively short distances within forests. Davidson et al. found that sporangia were generally not dispersed $>10 \mathrm{~m}$ from the canopy of infected bay laurel trees during rain events (12). In the current study, placement of infected leaf disks within submerged, impermeable plastic barriers did not result in heightened detection of $P$. ramorum in soils within $0.5 \mathrm{~m}$ of the barriers. In fact, the frequency of $P$. ramorum recovery outside the barriers closely reflects the natural levels of inoculum in the environment, as illustrated by the assessment of seasonal distribution of inoculum in soils at JLSP.

Soilborne inoculum may play a role in the survival, dispersal, and reproduction phases of the SOD disease cycle in infested forests. Soil may serve as an inoculum reservoir in natural ecosystems, supporting spore production and also aboveground infection of foliage and twigs by rain splash of inoculum. As forestry strategies are developed to manage aboveground inoculum levels (i.e., selective host removal), emergent forest vegetation should be observed for new infections initiated by splash dispersal of soil inoculum (19). Rapid removal of new infections at managed sites may impede the development of successive epidemics; however, chlamydospore production and pathogen persistence in soils may thwart long-term eradication and inoculum management strategies. Chlamydospore production in forest soils is mediated by a combination of environmental conditions and soil properties, with some soils suppressive to chlamydospore production. Though chlamydospore-infested media have been shown to initiate root

TABLE 6. Infection of aboveground bay laurel and tanoak by rain-splashed soil inoculum of Phytophthora ramorum from bare and litter covered forest soil

\begin{tabular}{lcccc}
\hline & & \multicolumn{3}{c}{ Infection $(\%)^{\mathrm{z}}$} \\
\cline { 3 - 5 } Exposure $^{\mathrm{x}}$ & Height $(\mathrm{cm})^{\mathrm{y}}$ & Bay, rain 1 & Bay, rain 2 & Tanoak \\
\hline Leaf litter & 30 & $0.0 \mathrm{c}$ & $1.7 \mathrm{~b}$ & $3.7 \mathrm{c}$ \\
Leaf litter & 8 & $1.8 \mathrm{c}$ & $3.5 \mathrm{~b}$ & $14.9 \mathrm{c}$ \\
Bare soil & 30 & $22.3 \mathrm{~b}$ & $5.2 \mathrm{~b}$ & $38.3 \mathrm{~b}$ \\
Bare soil & 8 & $75.0 \mathrm{a}$ & $35.4 \mathrm{a}$ & $75.9 \mathrm{a}$ \\
\hline
\end{tabular}

${ }^{x}$ Fifty inoculated rhododendron leaf disks were placed on soil surfaces $\left(700 \mathrm{~cm}^{2}\right)$ and either covered with a light dusting of soil or with a layer of leaf litter.

${ }^{y}$ Seven leaf-bearing twigs of bay laurel and tanoak were suspended either 8 or $30 \mathrm{~cm}$ above each infested area of forest floor. Eight replicates of each combination of inoculum exposure and suspension height were utilized for each tissue type.

${ }^{z}$ The potential for soil inoculum to infect aboveground tissues of tanoak and bay laurel during rain events was investigated by suspending either bay laurel or tanoak twigs above artificially infested soil. Uninfected bay laurel and tanoak tissue was placed in the field for two rain events spanning 6 to 13 February and 21 February to 1 March 2007. The percentage of bait tissues infected with $P$. ramorum was determined by isolating lesions onto PARP. The infection levels after two rain events were statistically similar for tanoak, so average percent infection of tanoak is combined over rain events. Different letters within columns represent significant differences based on the Waller-Duncan K-ratio test $(\mathrm{K}=100)$. infections of ornamentals $(5,6,40)$, the infectivity of these propagules on roots of plants in invaded forests is unknown. Further research is needed to elucidate the role of chlamydospores in forest soils and the mechanisms of suppression of chlamydospore production in moist, redwood-associated soils.

\section{ACKNOWLEDGMENTS}

This research was funded by the United States Department of Agriculture Forest Service Pacific Southwest Research Station, the Gordon and Betty Moore Foundation, and the American Philosophical Society. The California State Parks and, specifically, the staff at Jack London State Park were integral in allowing this research at their site. We thank H. Patterson, K. Falk, J. Bienapfl, H. Mehl, A. Brauer, A. Ouguchi, K. Huryn, K. Sandhu, G. Ritokova-Owens, and S. Murphy for field and laboratory assistance; and M. Benson, R. Bhat, E. Nelson, and two anonymous reviewers for their comments.

\section{LITERATURE CITED}

1. APHIS. 2005. Pest Detection and Management Programs: Program Update Sudden Oak Death. Published online by U.S. Department of Agriculture-Animal and Plant Health Inspection Service. http://www. aphis.usda.gov/ppq/ispm/sod/updates/update1-10-05.pdf

2. Aryantha, I. P., Cross, R., and Guest, D. I. 2000. Suppression of Phytophthora cinnamomi in potting mixes amended with uncomposted and composted animal manures. Phytopathology 90:775-782.

3. Bienapfl, J., Zanzot, J., Murphy, S., Garbelotto, M., and Rizzo, D. 2005. Isolation of a new lineage of Phytophthora ramorum from asymptomatic stems and roots of a commercial lot of rhododendron in California. (Abstr.) Phytopathology 95(suppl.):S9.

4. California Soil Resource Lab. Published online by the University of California-Davis, CA. http://casoilresource.lawr.ucdavis.edu/drupal/

5. Colburn, G., Sechler, K., and Shishkoff, N. 2005. Survivability and pathogenicity of Phytophthora ramorum chlamydospores in soil. (Abstr.) Phytopathology 95:S20.

6. Colburn, G. C., and Shishkoff, N. 2005. Density of Phytophthora ramorum chlamydospores in soil necessary to cause infection. (Abstr.) Phytopathology 96:S25.

7. Davidson, E. A., Belk, E., and Boone, R. D. 1998. Soil water content and temperature as independent or confounded factors controlling soil respiration in a temperate mixed hardwood forest. Global Change Biol. 4:217-227.

8. Davidson, J. M., Fichtner, E. J., Patterson, H. A., Falk, K. R., and Rizzo, D. M. 2005. Mechanisms underlying differences in inoculum production by Phytophthora ramorum in mixed-evergreen versus tanoak-redwood forest in California. Page 500 in: Proc. Sudden Oak Death Second Sci. Symp.: The State of our Knowledge, Monterey, CA. Gen. Tech. Rep. PSW-GTR-196. S. J. Frankel, P. J. Shea, and M. I. Haverty, eds. Pacific Southwest Research Station, Forest Service, United States Department of Agriculture, Albany, CA.

9. Davidson, J. M., Patterson, H. A., and Rizzo, D. M. 2008. Sources of inoculum of Phytophthora ramorum in a redwood forest. Phytopathology 98:860-866.

10. Davidson, J. M., Rizzo, D. M., Garbelotto, M., Tjosvold, S., and Slaughter, G. W. 2002. Phytophthora ramorum and sudden oak death in California: II. Transmission and Survival. U.S. Dep. Agric. For. Serv. Gen. Tech. Rep. PSW-GTR-184.

11. Davidson, J. M., Werres, S., Garbelotto, M., Hansen, E. M., and Rizzo, D. M. 2003. Sudden oak death and associated diseases caused by Phytophthora ramorum. Published online. Plant Health Progress doi: 10.1094/PHP-2003-0707-01-DG.

12. Davidson, J. M., Wickland, A. C., Patterson, H. A., Falk, K. R., and Rizzo, D. M. 2005. Transmission of Phytophthora ramorum in mixedevergreen forest in California. Phytopathology 95:587-696.

13. Erwin, D. C., and Ribeiro, O. K. 1996. Phytophthora Diseases Worldwide. American Phytopathological Society, St. Paul, MN.

14. Fichtner, E. J., Benson, D. M., Diab, H. G., and Shew, H. D. 2004. Abiotic and biological suppression of Phytophthora parasitica in a horticultural medium containing composted swine waste. Phytopathology 94:780-788.

15. Fichtner, E. J., Lynch, S. C., and Rizzo, D. M. 2007. Detection, distribution, sporulation, and survival of Phytophthora ramorum in a California redwood-tanoak forest soil. Phytopathology 97:1366-1375.

16. Garbelotto, M., Davidson, J. M., Ivors, K., Maloney, P. E., Hüberli, D, and Rizzo, D. M. 2003. Non-oak native plants are the main hosts for the sudden oak death pathogen in California. Calif. Agric. 57:18-23. 
17. Goheen, E. M., Hansen, E. M., Kanaskie, A., McWilliams, M. G., Osterbauer, N., and Sutton, W. 2002. Eradication of sudden oak death in Oregon. Plant Dis. 86:441.

18. Hansen, E. M., and Hamm, P. B. 1996. Survival of Phytophthora lateralis in infected roots of Port Orford Cedar. Plant Dis. 1075-1078.

19. Hansen, E. M., Kanaskie, A., Prospero, S., McWilliams, M., Goheen, E. M., Osterbauer, N., Reeser, P., and Sutton, W. 2008. Epidemiology of Phytophthora ramorum in Oregon tanoak forests. Can. J. For. Res. 38:1133-1143.

20. Hansen, E. M., Reeser, P. W., Sutton, W., Winton, L., and Osterbauer, N. 2003. First report of A1 mating type of Phytophthora ramorum in North America. Plant Dis. 87:1267.

21. Hoitink, H. A. J., and Boehm, M. J. 1999. Control within the context of soil microbial communities: A substrate-dependent phenomenon. Annu. Rev. Phytopathol. 37:427-446.

22. Hoitink, H. A. J., Inbar, Y., and Boehm, M. J. 1991. Status of compost amended-potting mixes naturally suppressive to soilborne diseases of floricultural crops. Plant Dis. 75:869-873.

23. Huang, S. C., and Ko, W. H. 1978. Biology of chlamydospores, sporangia, and zoospores of Phytophthora cinnamomi in soil. Phytopathology 68:726-731.

24. Hüberli, D., Tommerup, I. C., and Hardy, G. E. St. J. 2000. False-negative isolations or absence of lesions may cause mis-diagnosis of diseased plants infected with Phytophthora cinnamomi. Australas. Plant Pathol. 29:164-169.

25. Konam, J. K. 1992. The epidemiology of Phytophthora palmivora diseases of cocoa in Papua New Guinea. PGDSci. thesis, University of Papua New Guinea.

26. Konam, J. K., and Guest, D. I. 2002. Leaf litter mulch reduces the survival of Phytophthora palmivora under cocoa trees in Papua New Guinea. Australas. Plant Pathol. 31:381-383.

27. Kuske, C. R., and Benson, D. M. 1983. Survival and splash dispersal of Phytophthora parasitica, causing dieback of rhododendron. Phytopathology 73:1188-1191.

28. Maloney, P. E., Lynch, S. C., Kane, S. F., Jensen, C. E., and Rizzo, D. M. 2005. Establishment of an emerging generalist pathogen in redwood forest communities. J. Ecol. 93:899-905.

29. Manter, D. K, Karchesy, J. J., and Kelsey, R. G.. 2006. The sporicidal activity of yellow-cedar heartwood, essential oil and wood constituents towards Phytophthora ramorum in culture. For. Pathol. 36:297-308.

30. Manter, D. K., Kelsey, R. G., and Karchesy, J. J. 2007. Antimicrobial activity of extractable conifer heartwood compounds toward Phytophthora ramorum. J. Chem. Ecol. 33:2133-2147.

31. Masago, H., Yoshikawa, M., Fukada, M., and Nakanishi, N.1977. Selective inhibition of Pythium spp. on a medium for direct isolation of Phytophthora spp. from soils and plants. Phytopathology 67:425-428.

32. Nesbitt, H. J., Malajczuk, N., and Glenn, A. R. 1979. Effect of organic matter on the survival of Phytophthora cinnamomi Rands in soil. Soil
Biol. Biochem. 11:133-136.

33. Orchard, V. A., and Cook, F. J. 1983. Relationship between soil respiration and soil moisture. Soil Biol. Biochem. 15:447-453.

34. Parke, J. L., Bienapfl, J., Oh, E., Rizzo, D., Hansen, E., Buckles, G., Lee, C., and Valachovic, Y. 2005. Natural infection of tanoak seedling roots by Phytophthora ramorum. (Abstr.) Phytopathology 96:S90.

35. Parke, J. L., and Lewis, C. 2007. Root and stem infection of rhododendron from potting medium infested with Phytophthora ramorum. Plant Dis. 91:1265-1270.

36. Parke, J. L, Linderman, R. G., Osterbauer, N. K., and Griesbach, J. A. 2004. Detection of Phytophthora ramorum blight in Oregon nurseries and completion of Koch's postulates on Pieris, Rhododendron, Viburnum, and Camellia. Plant Dis. 88:87.

37. Rizzo, D. M., Garbelotto, M., Davidson, J. M., Slaughter, G. W., and Koike, S. T. 2002. Phytophthora ramorum as the cause of extensive mortality of Quercus spp. and Lithocarpus densiflorus in California. Plant Dis. $86: 205-214$.

38. Rizzo, D. M., Garbelotto, M., and Hansen, E. M. 2005. Phytophthora ramorum: Integrative research and management of an emerging pathogen in California and Oregon forests. Annu. Rev. Phytopathol. 43:309-335

39. Shew, H. D., and Benson, D. M. 1983. Qualitative and quantitative soil assays for Phytophthora cinnamomi. Phytopathology 72:1029-1032.

40. Shishkoff, N. 2007. Persistence of Phytophthora ramorum in soil mix and roots of nursery ornamentals. Plant Dis. 91:1245-1249.

41. Shishkoff, N., and Senesac, A. 2005. Susceptibility to Phytophthora ramorum of roots and shoots of common container weeds. (Abstr.) Phytopathology. 95:S96.

42. Skopp, J., Jawson, M. D., and Doram, J. W. 1990. Steady-state aerobic microbial activity as a function of soil water content. Soil Sci. Soc. Am. J. 54:1619-1625.

43. Smith, A. L. 2007. Biology of chlamydospores of Phytophthora ramorum. MS thesis, Oregon State University.

44. Tooley, P. W., Browning, M., and Berner, D., 2008. Recovery of Phytophthora ramorum following exposure to temperature extremes. Plant Dis. 92:431-437.

45. Tsao, P. H. 1983. Factors affecting isolation and quantitation of Phytophthora from soil. Pages 219-236 in: Phytophthora, Its Biology, Taxonomy, Ecology, and Pathology. D. C. Erwin, S. Bartnicki-Garcia, and P. H. Tsao, eds. American Phytopathological Society, St. Paul, MN.

46. Werres, S, and de Merlier, D. 2003. First detection of Phytophthora ramorum mating type A2 in Europe. Plant Dis. 87:1266.

47. Werres, S., Marwitz, R., Man In't Veld, W. A., De Cock W. A. M., Bonants, P. J. M., De Weerdt, K., Ilieva, E., and Baayen, R. P. 2001. Phytophthora ramorum sp. Nov., a new pathogen on Rhododendron and Viburnum. Mycol. Res. 105:1155-1165.

48. Zentmyer, G. A., and Mircetich, S. M. 1966. Saprophytism and persistence in soil by Phytophthora cinnamomi. Phytopathology 56:710-712. 